九州大学学術情報リポジトリ

Kyushu University Institutional Repository

Rediscovering Asianness: the role of institutional discourses in APEC, 1989-1997

大賀，哲

http://hdl. handle. net/2324/19747

出版情報: International Relations of the Asia-Pacific. 4 (2)，pp.287-317，2004-08. 0xford University Press

バージョン:

権利関係 : 


\title{
Rediscovering Asianness: the role of institutional discourses in APEC, 1989-1997
}

Toru Oga

Nakamachi 1-25-16, Meguro-Ku, Tokyo 153-0065, Japan. Email: toruoga@m5.dion.ne.jp

\begin{abstract}
Asia-Pacific Economic Cooperation (APEC) emerged as the largest regional body in history and gave rise to two institutional discourses: open regionalism and Asian values. Open regionalism entailed the articulation of a non-discriminatory and inclusive regionalism. While endorsing the idea of an Asia-Pacific community, APEC has suffered as a result of clashes between two of its core constituencies, its Asian and Anglo-Saxon members. In reality, APEC had lost its articulatory role by the mid-1990s; no significant agreements have been concluded since the Osaka summit of 1995. However, Asian values have emerged as a vehicle for the advocacy of Asian identity, instead of the open regionalism of APEC. This paper, then, focuses primarily on these two institutional discourses and explores the evolution of APEC; how discourses on 'Asianness' have been articulated as an alternative to the idea of an Asia-Pacific identity.
\end{abstract}

\section{Introduction}

An epochal aspect of Asia-Pacific Economic Cooperation (APEC) was the establishment of a trans-regional economic body involving East Asia, North America, the Pacific Basin and Latin America. The objective was to counter regionalist and protectionist developments in the world economy, such as those espoused by the European Union (EU) and in the North American Free Trade Agreement (NAFTA). APEC articulated 'open regionalism': this entailed non-discriminatory and inclusive regionalism. However, despite its magnificent ideals, APEC has not succeeded in its objectives. APEC 
contains at least two antagonistic camps: the Asian members (China, Malaysia and Singapore) and the Anglo-Saxon members (Australia, Canada, New Zealand and the United States). Although APEC advocated open regionalism during the first half of the 1990s, in practice, it has not reached any significant agreements since the Osaka summit of $1995 .^{1}$ Instead, the discourse on open regionalism was gradually superceded by an increased sense of Asian regional identity (as opposed to Asia-Pacific identity). This is reflected in the emergence of the discourse on so-called Asian values.

The primary focus of this paper is two institutional discourses: declining open regionalism and the rise of Asian values in observing the institutional management of APEC. An institutional discourse is defined as a hegemonic narrative structure of regimes. In other words, this study applies what Gramsci called 'hegemony' to the study of international regimes. Gramsci wrote

[a] 'crisis of authority' is spoken of: this is precisely the crisis of hegemony, or general crisis of the State. . . If the ruling class has lost its consensus, i.e., is no longer 'leading' but only 'dominant', exercising coercive force alone, this means precisely that the great masses have become detached from their traditional ideology, and no longer believe what they used to believe previously. (Gramsci, 1972, pp. 210, 275-276)

Accordingly, hegemony is defined as the articulation of consent; institutional discourses signify which discourses and narratives are defined as constituting consent to a regime. Thus, this paper assesses how the discourse on open regionalism has declined and Asian values have been articulated. The focus of this paper is on discourses, but this does not imply the complete rejection of analyses of power and interest, because power and interest are themselves kinds of discursive practices (Griggs and Howarth, 2000). The paper rejects the false dichotomy between material and ideational factors, since both are shaped by discourses. The institutional stability of APEC cannot be reduced to rough power- and interest-relations. Realist power politics, for instance, is unable to explain why a less powerful state such as Malaysia is able to radically challenge US domination of APEC (e.g. through the promotion of an East Asian Economic Caucus, EAEC), despite the fact that the United States still possesses hegemonic economic and military capabilities.

1 Although the APEC summits at Subic Bay in 1996 and Montreal in 1997 initiated early voluntary sectoral liberalization (EVSL), negotiations have encountered a number of difficulties. These have stirred up an ideological debate between liberalization and co-operation (the Anglo-Saxon members prefer the former, the Asian members the latter). Productive negotiations were completed at Osaka in 1995. Thereafter, summits and negotiations have caused more antagonism than harmony (see Wesley, 2001). 


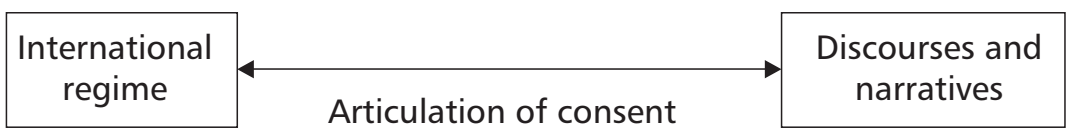

Figure 1 Regime and discourses

Thus, the primary method that this paper employs is a discourse analysis that can reveal the evolution of discursive formation. Reviewing institutional discourses demonstrates how institutions rise and fall. This paper presumes regimes to be discursive practices, because the constitution of a regime is affected by discursive and narrative structures, and vice versa (see Figure 1), shaped by an articulation of consent. A regime articulates particular discourses, and a discourse, at the same time, propagates the constitution of a regime. That is, discourses 'reinforce power, but they also subvert and conceal it' (Flyvbjerg, 2001, p. 124).

Open regionalism, on the one hand, bridged the gap between the Asian and Anglo-Saxon members, in constituting APEC, and APEC also articulated the discourse on open regionalism. Asian values, by contrast, play a deconstructionist role for the APEC institutional narrative; they disarticulate open regionalism and constitute anti-APEC sentiment. In other words, a deconstruction of APEC occurred through the rediscovery of 'Asianness'; the hegemonic discourse on the region has shifted from open regionalism to Asian regionalism (i.e. from an Asia-Pacific identity to an East Asian identity).

This paper comprises five sections. The first section reviews three perspectives on regime formation: power-, interest- and knowledge-based regime theories, respectively. It also demonstrates the value of discourse theory for regime analysis: how the discursive perspective better explains the articulation and disarticulation of APEC compared to other perspectives. The second section reviews the articulation and disarticulation of APEC: how the discourse on open regionalism was constructed and began to be deconstructed. The third section then examines the disarticulation of APEC: how Asian values have emerged instead of open regionalism. The fourth section examines three specific 'Asian' projects that contest the Asia-Pacific discourse, as case studies: a series of APEC summits (Seattle, Bogor and Osaka), an EAEC proposal and the Bangkok Declaration. This section examines how these specific cases articulated the dichotomy between Asia and the West. The final section provides an overview of how Asia has rediscovered its Asianness: discourses of Asianness developed in the 1990s along with the antagonism between Asian and Asia-Pacific images of regional identity. This section also reviews how institutional discourses have moved from open regionalism towards Asian values. 


\section{Discourse theory: an alternative framework of analysis}

International regimes have been one of the major issues in the study of international relations. ${ }^{2}$ There are, as Table 1 describes, three broad perspectives on international regime formation: the power-, interest-, and knowledgebased perspectives (Hasenclever, 1997).

Table 1 Perspectives on regime formation

\begin{tabular}{llll}
\hline & Power-based & Interest-based & Knowledge-based \\
\hline Basic variable & Power & Interest & Discourse \\
Theoretical orientation & Rationalism & Rationalism & Post-positivism \\
Regime as... & Hegemonic alliance & Mutual expectation & Knowledgeable practice \\
\hline
\end{tabular}

This section comprises three subsections. The first section reviews three perspectives on regimes and their limitations, the second introduces a discursive approach to regime analysis, and the final section defines a research strategy for analysing APEC.

\subsection{Three perspectives on regimes}

Firstly, the power-based perspective identifies regimes as hegemonic alliances, and relative power capabilities are central to an explanation of regime evolution. Regimes, according to this perspective, are only possible where a single hegemonic state exists; the stability of the international system depends on the presence of hegemonic power, since a hegemonic state provides for the creation and maintenance of a regime (see Kindleberger, 1973; Krasner, 1976; Gilpin, 1981).

In contrast, the second regime theory I have identified, the interest-based perspective, emphasizes that states share mutual expectations and interests in several ways: international politics is not zero-sum. Regimes and cooperation are products of policy co-ordination among states sharing mutual interests. Although a hegemonic state plays some role in the creation of regimes, non-hegemonic regimes and co-operation are also possible if states share mutual expectations and benefits (Keohane, 1984).

Finally, knowledge-based regime theory assumes that regimes fundamentally rely on practical and working discourses that are shared by states. Regimes and discourses are established and re-established with reference to common identities, interpretations and norms (Kratochwil, 1989). A number of studies on the epistemic community and the security community (Adler, 1992, 1997; Haas, 1992) demonstrate that member-states share common

2 Regimes are often defined as 'implicit or explicit principles, norms, rules, and decision-making procedures around which actors' expectations converge in a given area of international relations' (Krasner, 1983, p. 2). 
understandings regarding particular problems; Ruggie refers to this phenomenon as a 'social episteme' (1993, p. 157). In short, this approach recognizes regimes as social constructions that emerge through knowledge-constituting practices that are less amenable to empirical observation (Kratochwil and Ruggie, 1986; Kratochwil, 1988; Wæver, 1996).

The main presumption of this paper is that regimes are constituted by the evolution of institutional discourses. Numerous assumptions made from the power-based perspective can be disproved by empirical facts: Japan and Australia, founding members of APEC, were not hegemonic powers at the time of its inception. Furthermore, Japan and the United States, in the first half of the 1990s, co-operated in the management of APEC, and this co-operation generated absolute rather than relative gains (Krauss, 2000). The interest-based perspective explains the early management of the APEC, where many countries shared expectations regarding the mutual benefits of open regionalism, despite its limitations. However, the interest-approach fails to describe why and how Asian members abandoned the ideology of open regionalism. Otherwise, the major reason for the failure of this approach is the timing of the emergence of the regimes (Kahler, 1995; Krauss, 2000). While Asian member-states continue to benefit from open regionalism since they depend on international trade, Asians lost their desire for the constitution of an Asia-Pacific community and articulated an Asian community with associated Asian values. In short, materialist-functionalist explanations cannot help in explaining regimes, because they do not focus properly on the institutional discourses that articulate power and interest. The chief weakness of the power- and interest-based approaches lies in their reductionism; articulation is a contingent practice that cannot reduce one to the other. Policy co-ordination does not appear in the absence of ideational and discursive factors, since national interest stems from a combination of power and values (Higgott, 1997).

The knowledge-based perspective provides a better account of the evolution of ideational and discursive factors in regime formation. The problem with this approach, however, lies in its ambiguous conceptualization and methodology: how are discourses and epistemes articulated? What is a discourse? How can a discourse be measured? By relying on discourse theory, this paper defines a discourse as 'a social practice through which thoughts and beliefs are themselves constituted' (Weldes and Saco, 1996, p. 371). A discursive practice 'generates narrative structures that have a constitutive effect on the subsequent discursive and economic practices of these actors' (Hall, 2003, p. 73). In short, discourse analysis crystallizes the meanings of a narrative structure by analysing how political and social forces are articulated within a contingent and undecidable structure (Hoffman and Knowles, 1999; Howarth, 2000). 


\subsection{The core logic of discourse theory}

According to influential critics, discourse theory is methodologically baseless and laissez faire. It is incapable of yielding generalizations which can be subjected to systematic empirical testing (see Keohane, 1988, 1996; Krasner, 1996; Mearsheimer, 1998). Discourse theory does not offer a research programme that explains how particular discourses rise and decline. ${ }^{3}$ For example, Keohane argues

Indeed, the greatest weakness of the reflective school lies not in deficiencies in their critical arguments but in the lack of a clear reflective research program that could be employed by students of world politics. Waltzian neorealism has such a research program: so does neoliberal institutionalism, which has focused on the evolution and impact of international regimes.

(Keohane, 1988, p. 392)

In a similar vein, Mearsheimer argues that discourse analysis fails to address the issue of "what determines why some discourses become dominant and others lose out in the marketplace of ideas? What is the mechanism that governs the rise and fall of discourses?' (1998, p. 374). These criticisms are not all wrong; although a number of research programmes have employed socalled discourse analysis in recent years and have developed ontological and epistemological bases that dislodge dominant theoretical interpretations, discourse analysis in general lacks a substantive methodology.

A methodological question can be posed: does discourse theory provide a clear methodology and can it generate research programmes? For the purpose of understanding the mechanism of discursive practice, it is necessary to address two methodological questions. How are particular discourses articulated? Why are some discourses articulated more strongly than others? Some discourse analysts do not address these questions. An exception is Ernesto Laclau's discourse theory $(1990,1996)$, which explains the operationalization of discourses.

There are two mechanisms operationalizing the evolution of discourses: antagonism and articulation. On the one hand, antagonism signifies the 'impossibility of social structure', exclusionary practices between the inside and the outside: the outside blocks the constitution of the inside. Antagonism, in other words, emerges between two opposite poles in a social structure, between inside/outside, self/other, friend/enemy and so forth: antagonism constitutes a vehicle which is used in configuring 'we-ness'.

3 Keohane defines a research programme as having 'particular explanatory variables to emphasize, which explains both their frequent disagreements and their potential complementarity' (1996, p. 471), and Krasner attacks discourse analysis by stating that it has 'no methodology for adjusting among competing claims' (1996). 
In our conception of antagonism, on the other hand, we are faced with a 'constitutive outside'. It is an 'outside' which blocks the identity of the 'inside'. . . . Derrida has shown how an identity's constitution is always based on excluding something and establishing a violent hierarchy between the two resultant poles - form/matter, essence/accident, black/white, man/ woman etc. (Laclau, 1990, pp. 17, 32)

Accordingly, open regionalism (the outside) blocks the constitution of Asian values (the inside). This blockage results in the endorsement of Asian solidarity as a backlash. The constitution of Asian values is articulated by the antagonism between Asia and the West.

On the other hand, particular discourses possess two opposite characteristics: their constitutive signifiers can either be floating or empty. Since every discourse possesses incomplete and contingent meanings, different meanings constitute different contexts - this is called a 'floating signifier' (Laclau, 1990, p. 28; see also Torfing, 1999, p. 62). For instance, the term 'Asia' provides different meanings in different contexts, for example when articulated in the context of a nationalist, liberal or culturalist discourse. The second feature of a discourse is that terms do not have fixed content and meaning terms can be 'empty signifiers' (Laclau, 1996, ch. 3). Again, the term 'Asia' does not constitute a fixed concept of what Asia is and what it is not. Rather, the meanings of 'Asia' are contingent and articulated with reference to social contexts. In short, the emptiness of discourses plays a role in symbolizing and representing different identities united into a hegemonic discourse. Each discursive practice is not characterized by a supreme density of meaning but by a certain emptying of content to facilitate the structural role of unifying a discursive terrain (Torfing, 1999, pp. 98-99). Although there is antagonism towards the outside, it is not sufficient for hegemony to emerge, because a hegemonic discourse has to articulate different social forces into a single hegemonic signifier. In other words, political discourses need to be articulated by an empty signifier, because an empty form of discourses is filled by imaginable political practices (Torfing, 1999, p. 81). '[T]erms such as 'the unity of the people', the 'welfare of the country', and so forth, as something that antagonistic political forces claim to ensure through totally different political means, have to be necessarily empty in order to constitute the aim of a political competition' (Laclau and Zac, 1994, p. 37).

Table 2 describes the overall mechanisms of discursive practice; the logic of equivalence signifies a strong articulation that fixes different signifiers into a common project of hegemony, whereas the logic of difference floats a common signifier and hegemony is unable to be articulated. More importantly, there are three required conditions for a particular signifier to fix an empty space: availability, credibility and strategically placed agents. First, 
Table 2 Mechanisms of discursive practice

\begin{tabular}{lll}
\hline & Strong articulation & Weak articulation \\
\hline Discursive moment & Logic of equivalence & Logic of difference \\
Signifier is... & Fixed in an empty place & $\begin{array}{l}\text { Floating in a plurality of } \\
\text { meanings }\end{array}$ \\
\hline
\end{tabular}

potential signifiers have to be available to become hegemonic in a way that no other discourse can constitute an alternative hegemonic formation (Laclau, 1990, p. 66). Second, signifiers have to be credible in that the constitution of a hegemonic discourse has to satisfy the basic principles and articulated consensus of particular social arenas (Laclau, 1990). Finally, the constitution of an empty hegemony requires particular social agents that articulate and place empty signifiers before their hegemonic projects (Griggs and Howarth, 2000, pp. 59-60).

\subsection{Research strategy}

Discourse analysis then focuses on discourses (processes of producing meaning and narrative in given contexts) and explores how discursive practices construct particular meanings in political and social structures. Therefore, it can crystallize the evolution of institutional discourses by underpinning discursive and narrative structures. Indeed, open regionalism and Asian values are questions of discourse, the constitution of particular meanings rather than questions of power and interest.

Discourse analysis can uncover one thing: discourse. Whenever discourse and the structures thereof are interesting in themselves, discourse analysis makes sense ... The analysis should be conducted on texts that are central in the sense that if a security discourse is operative in this community, it should be expected to materialize in this text because this occasion is sufficiently important. (Buzan et al., 1998, p. 177)

Discourse theory is problem-driven rather than theory-driven. Theorydriven research tends to vindicate a particular theoretical framework rather than investigating specified problems, whereas a problem-driven approach seeks the configuration and constitution of problems as empirical objects of analysis and also dislodges dominant bodies of theoretical discourse (see Shapiro, 2002). Discourse theory addresses three methodological tasks. The first task is to read a wide range of discursive information, such as official and unofficial documents, public speeches, surveys, newspapers and so forth, in order to observe the evolution of discourse. The second task is to interpret how political and social forces articulate particular discourses according to a theoretical framework: and the final task is to evaluate an entire discur- 
sive formation with reference to material structures (Buzan et al., 1998; Howarth, 2000). Discourse theory comprises more than textual analysis, in that analyses of textual interpretation need to be assessed against empirical findings.

A further methodological critique is presupposed: how can discourse analysis reveal particular discursive practices to be central to the social context? For instance, discourse analysts can selectively and intentionally focus on particular practices that have an outcome they would like to explain. Positivists who are critical of discursive methodology point to the problems of selection bias and verification here. With regard to such critiques, this paper employs two particular frameworks: case studies and comparative methods. As Flyvbjerg argued, social 'scientists' tend to under-evaluate and misunderstand the merits of case studies; the hegemonic positivist culture seems to contend that context-independent general knowledge is more valuable than context-dependent specific knowledge, and it elaborates the fact that case studies cannot provide generalised theses. The quantitative method is more helpful in testing hypotheses and building theory (Flyvbjerg, 2001, pp. 66-67).

However, these criticisms fail to grasp the numerous functions of case studies. Generally, a specific knowledge of case studies can help in the construction of general theoretical propositions, which 'move from the lower to the higher level' (Flyvbjerg, 2001, p. 71). For instance, while Galileo's famous experiment on the law of gravity falsified Aristotle's thesis, it did not engage a multitude, a multiplicity and a wide range of observations. The single, case-specific testing would construct a general proposition about gravity. How can case studies provide the basis for general theorization? There are four specific functions of case studies (Flyvbjerg, 2001, pp. 77-81). First, extreme and deviant cases highlight a particular and specific dramatic observation. Galileo's experiment belongs to this category. Mahathir's EAEC proposal highlights a discursive constitution of Asia rather than the Asia-Pacific region. Second, critical cases can be used for demonstrating or disproving theoretical hypotheses. They allow the logical deduction that if 'less likely' cases can demonstrate a proposition, then it can also apply to 'more likely' cases. Conversely, if 'more likely' cases confirm a hypothesis, it is then likely to apply to 'less likely' cases. This paper chooses three APEC summits that are 'more likely' in testing the evolution of institutional discourses. Third, to anticipate variation, a variety of case studies need to be selected. The three case studies in this paper, the APEC summits, the EAEC proposal and Bangkok Declaration, arose in different contexts: intergovernmental discourse, cultural discourse (Asian versus Anglo-Saxon) and social discourse on human rights, respectively. Finally, paradigmatic cases provide 
Table 3 Selection of cases

\begin{tabular}{lll}
\hline & Dimension & Characteristics \\
\hline APEC summits & Economical & Critical case \\
EAEC Proposal & Political & Deviant case \\
The Bangkok Declaration & Social & Paradigmatic case \\
\hline
\end{tabular}

an accurate representation of a wider field in a given realm. Such usage of case studies can also counter verification problems.

Table 3 summarizes the selection of cases in the paper: APEC summits represent a critical case, the most-likely case in observing discursive practices. The EAEC proposal and the Bangkok Declaration are deviant and paradigmatic cases that respectively highlight the transformation of discourses.

On the other hand, comparative methods can also be helpful. Although discourse theory is conducted with specific descriptions, it can be used for explaining and testing hypotheses (even if it does not employ quantitative observations). This is because comparative methods of discourse analysis can comprise descriptive interpretations of numerous empirical phenomena and show the significant similarities and differences among a group of selected cases. That is, these comparative methods can generate an overall depiction in demonstrating given hypotheses and theses. Moreover, comparative methods, associated with extreme and maximum variation cases, unravel significant factors in explaining and understanding discursive formations. Finally, comparisons of discursive formations can reveal a configuration of discourses: how a particular discourse is deconstructed and a new one is articulated. Therefore, as a consequence of three case studies, this paper compares how different discourses on Asianness have been constituted through a comparison of these cases. This paper thus comprises three listed cases and compares them in order to provide an overall account of the evolution of the APEC.

\section{APEC and open regionalism}

The previous section conceptualized the methodological strategy of discourse theory. This section explores how the discourse on open regionalism has been articulated and disarticulated.

\subsection{The articulation of open regionalism}

At the time of its launch, APEC included twelve members (Australia, Brunei, Canada, Indonesia, Japan, Malaysia, New Zealand, the Philippines, Singapore, South Korea, Thailand and the United States). China, Hong 
Kong and Taiwan were added in 1991; Mexico, Papua New Guinea and Chile in 1994; and Peru, Russia and Vietnam in 1998 (Das, 2001, pp. 26-27). The Joint Statement from the first meeting at Canberra in 1989 claims that

The Asia-Pacific region has a long-term common interest in promoting world-wide trade liberalisation. By working together, the region can inject positive views into a range of important international economic forums, including not only GATT, but the OECD and sectoral bodies.

(quoted by Wesley, 2001, p. 188)

Since its foundation, the APEC has clearly identified 'open regionalism' as signifying inclusive and non-discriminatory application of the open trade principle to all other regions. New members are welcome to join it (Das, 2001, p. 30; Yamazawa, 2001, p. 219). Although the principle of open regionalism is not essential, ${ }^{4}$ one of the strongest reasons for the creation of APEC was to counter the discriminatory and protectionist tide in Western Europe and North America (Higgott and Stubbs, 1995, p. 519). In discursive terms, open regionalism attempts to fill an empty place and its articulation is open-ended. APEC is not essentially open but its openness is only meaningful when confronting protectionist and exclusive regionalism. For instance, with regard to Mahathir's proposal that EAEC be an exclusionary Asian regional bloc, the former US Secretary of State, James Baker argued that 'APEC was trans-Pacific and it was inclusive, but EAEG [EAEC] is exclusive and draws a line down the Pacific. For those reasons, we were very much opposed to it' (interviewed by Funabashi, 1995, p 68). Furthermore, the Director-General of the International Trade Bureau of MITI, Muraoka, offered the following thoughts:

Should Japan follow the trend of discriminatory regionalism? No. Was Japan powerful enough to curb the trend? No. An option Japan could take was to commit itself to creating open regionalism by means of an AsiaPacific regional institution. Asia-Pacific regionalism should not only be consistent with regionalism, but it should also aim to promote globalism. We hope that MITI's plan could play a bridging role between regionalism and globalism. (interviewed by Terada, 2001, p. 209)

Thus, the basic feature of APEC is non-discriminatory open regionalism, looking outwards through the creation of a 'Pacific Community'; one may

4 Like any other political principle, there are some exceptions to open regionalism: the APEC is not absolutely open to newcomers. Colombia and Ecuador's membership applications were rejected by APEC. Additionally, numerous island nations of the Pacific (with the exception of Papua New Guinea) as well as Cambodia and Laos are non-APEC Asian-Pacific states (Scollay and Gilbert, 2001, p. 13). 
refer to this as 'New Regionalism' (Watanabe and Kikuchi, 1997). APEC and open regionalism, however, do not stand on neutral ground, but are closely associated with the globalist and liberalist agenda. The Eminent Persons Group (EPG), one of the key working groups of APEC, reports 'our commitment, above all, to the process of global liberalization, is thus in no way compromised. . . . Without any reservation whatsoever, we strongly oppose the creation of a trading bloc that would be inward-looking and that would divert from the pursuit of global free trade' (EPG, 1994, pp. 2-3).

\subsection{Clashes within APEC}

Despite a number of efforts to articulate open regionalism, the discourse was floating. APEC failed to construct Asia-Pacific states as reconciled to the unitary hegemony of liberalization. Instead, differences within APEC widened, and it can be seen as a 'trans-regional rather than a regional body' (Ravenhill, 2000, p. 329). The demand for a free trade principle differs between the two opposing blocs; the Anglo-Saxon bloc prefers economic liberalization, and the East Asian bloc focuses on economic and technical co-operation (Watanabe and Kikuchi, 1997; Gilpin, 2000; Ravenhill, 2000; Webber, 2001; Wesley, 2001).

After the Seattle summit of 1993 the United States clearly promoted open regionalism due to a strong desire for the economic liberalization of the Asia-Pacific region (Funabashi, 1995, pp. 156-157). The United States increasingly used APEC in an attempt to dominate the region and prevent the emergence of anti-American sentiment through the articulation of an Asian identity.

Despite the initial Australian initiative, increasingly the United States has taken over the leadership role in APEC and has used the organisation as a forum to maintain US power, embrace the exclusionary East Asian identity within an inclusionary 'Asia-Pacific' identity, and thereby prevent the creation of a regional identity centring on East Asian capitalist values - i.e., EAEC. (Hook, 1996, p. 193)

However, this only enhanced the growing antagonism between the United States and the Asian members of APEC. Countries such as China, Malaysia, the Philippines and Thailand strongly rejected the path to rapid liberalization. The United States advocated open regionalism, and proposed commitments that were too hasty and too legalistic in an attempt to accelerate the process of liberalization. These were not popular among the Asian members, and stimulated the emergence of Asian values and an Asian regional identity that emphasized economic co-operation and informal institution-building. The next section reveals how the discourse on Asian values was articulated in the region. 


\section{The emergence of Asian values and identity}

By 1995, APEC and the discourse on open regionalism began to be deconstructed, with tensions emerging between Asian and Western members. At the time, the invocation of Asian values played a significant role in increasing this antagonism, because these values constituted a direct challenge to open regionalism; Asian values radically endorse the 'differences' between Asian and Asia-Pacific identities. Although Asian values originally developed in Singapore and Malaysia, they have broadly penetrated the region, ${ }^{5}$ and have challenged strong statements of Western values, such as those articulated by Fukuyama and Huntington. Both Asian and Western values rely on a hierarchical value system (Asia over the West, or the West over Asia). The Asian values debate, in other words, is a debate between Orientalism and Occidentalism (Robinson, 1996): the Westerners attack Asia as being uncivilized and illiberal, whereas the Asians regard the West as being immoral and unjust. This section crystallizes two aspects of the Asian values debate: Orientalism and Occidentalism.

\subsection{Orientalism and Western values}

Let us refer to the writings of two American intellectuals who are greatly engaged in the advocacy of Western values. Francis Fukuyama, on the one hand, declares that the end of the Cold War constitutes the end of history, since no ideology can challenge the liberal economic ideal. On the other hand, Samuel Huntington asserts that the post-Cold War world order will be characterized by clashes of civilizations rather than clashes of ideologies or national interests. While both seem to argue opposite things - the victory of Western ideology and the emergence of rival civilizations - they articulated a similar end. Western civilization and its associated ideology constitute the pinnacle of human history, but there are still rival camps that oppose the Western liberal economic ideal. It is therefore legitimate for Western civilization to press for cultural homogenization along the lines of the liberal model. Fukuyama wrote, 'Despite the bad moral odor that capitalism has had for both the traditionalist-religious Right and the socialist-Marxist Left, its ultimate victory as the world's only viable economic system is easier to explain in terms of the Mechanism than is the victory of liberal democracy

5 One survey, involving 131 officials, scholars, business people and professionals from eight East Asian countries and the United States, asked respondents to choose a list of values they considered 'critically important' to people in their respective countries. In answer to all the questions, Asians tended to select Asian positions and Americans selected Western positions. That is, Asians selected an orderly society, harmony and accountability of public officials, while the Americans selected freedom of expression, personal freedom and individual rights. Of the Asians, 71\% responded that social stability is more important than personal freedom, while only $11 \%$ of Americans did so (Hitchcock, 1994). 
in the political sphere' (1993, pp. 90-91). Huntington also identified Asian (in particular Chinese and Islamic) civilizations as evil civilizations that need to be reformed according to the Western model of civilization (1996). Although Huntington listed a number of different civilizations, his argument was not radically pluralist but addressed the supremacy of Anglo-American civilization and the resurgence of the discourse on Orientalism, i.e. 'the West versus the Rest' (Ong, 1999, p. 189). Huntington's typology of civilizations converges with a dichotomy between Western values and non-Western values; Western values represent liberalism, rationality, social equality and individual rights, whereas non-Western values represent illiberalism, irrationality, social inequality and collective rights. He also continued

the promotion of democracy, human rights, and markets are far more central to American policy than to the policy of any other country. . . . A world without US primacy will be a world with more violence and disorder and less democracy and economic growth than a world where the United States continues to have more influence than any other country in shaping global affairs. (Huntington, 1993, p. 83)

Likewise, when Huntington visited Southeast Asia, which he described as 'illiberal', he justified American democracy as entailing

free, fair, and competitive elections that are only possible if there is some measure of freedom of speech, assembly and press, and if opposition candidates and parties are able to criticise incumbents without fear of retaliation. Democracy is thus not only a means of constituting authority, it is also a means of limiting authority. (cited by Ong, 1999, p. 193)

\subsection{Occidentalism and Asian values}

Against this backdrop, Asian challenges to Western values envision 'the rise of the East, and the fall of the West'. These discursive practices emphasize 'Occidentalism' or 'counter-Orientalism' (Rodan, 1996). Such challenges commonly point to the decline of Anglo-American hegemony and articulate the 'Asian way'. 6 They are epitomized in Mahathir's public speech in Hong Kong in 2000.

6 Despite variations in what people meant by Asian values, they signify an 'East Asian identity' and share at least the following features (Dupont, 1996; Milner, 1999). (i) An emphasis on the community rather than the individual, harmony in society rather than personal freedom, and considerable respect for hard work, political and social authority, and family loyalty. (ii) The sources of Asian economic success were attributed to Asian diligence and social harmony. (iii) Asia modernized, but did not Westernize; social and economic projects were constructed with specific reference to Asian culture. (iv) The rise of the East and the fall of the West presages a major international power transition, from Western Europe and North America towards East Asia. 
There was much talk of the twenty-first century becoming the Asian century. The Europeans were not going to have things their way very much longer. . . . The Countries of East Asia continued with their own ways of developing their economies. It looked like there was no stopping them. They were going to grow and they were going to continue to challenge the West. There was a good chance for the twenty-first century to become the Asian century . . . there is no reason why we should believe that what is being propagated by the West now - liberal democracy, free markets, a borderless world etc. would do any better in the long run.

(Mahathir, 2000)

In short, the Asian values metaphor of Occidentalism usually demonstrates the dysfunctionality of Western values: 'Many of the assertions of Asian values are also imbued with post-colonial sensitivities and resentments, imbuing East Asian cultural regionalism with a sense of distinctness from the non-East Asian world, and particularly the West' (Wesley, 1997, p. 539). In the Orientalist view of nineteenth-century Europe, the West was defined as rational and progressive, while Asia was seen as irrational and underdeveloped (Turner, 1978). From the opposite perspective, Occidentalism signifies the rise of Asia and the fall of the West. Singapore Prime Minister Goh Chok Tong, for instance, notes that

Societies can go wrong quickly. American and British societies have changed profoundly in the last 30 years. Up to the early 60 s they were disciplined, conservative, with the family very much the pillar of their societies. Since then, both the US and Britain have seen a sharp rise in broken families, teenage mothers, illegitimate children, juvenile delinquency, vandalism and violent crime. (1994, p. 4)

Accordingly, Asian values strongly endorse a reversed hierarchy: the Orient over the Occident. 'Asia' represents community, harmony and miracles, whereas the 'West' represents individuality, immorality and decline. Thus, it is not easy to apply Western values to Asian society.

'Asian culture', with its emphasis on the group rather than the individual, was ideally suited to modern, industrial society. Liberalism, with its emphasis on the rights and freedoms of the individual was, in contrast, portrayed as producing crime-ridden societies in moral decay and with little social discipline or concern for the broader interests of community.

(Robinson, 1996, p. 310)

An overall discursive picture of Asian and Western values appears in Figure 2. Western values are strongly associated with 'Orientalism', which dichotomizes the civilized West as inside, and uncivilized Asia as outside. 


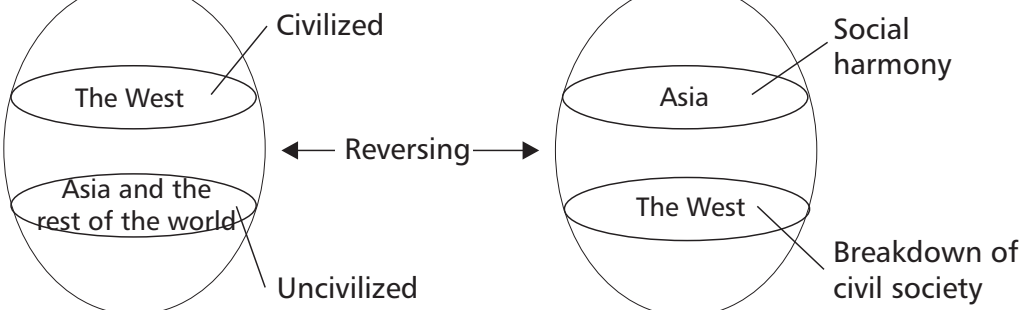

Figure 2 Orientalism and Occidentalism

Asian values strongly represent the West as outside: there is a binary opposition between harmonious Asia inside and broken social order in the West outside. Thus, Asian values constitute a reversal of Orientalism. 'Significantly, the essentials of 'Asian values' have been defined principally in opposition to what is commonly referred to as 'Western liberalism' which is seen, among other things, to be characterized by excessive individualism and a propensity for protestation and open political conflict' (Rodan, 1996, p. 330).

Despite these vigorous dichotomies, there are no ontological differences between Asian and Western values; many argue that 'Asian values were once also Western values' (Goh, 1994; Mahathir, 1995). While there are differences between Asian values and Western conservatism with regard to specific issues (such as strong versus minimal government, strong versus minimal gun regulations, etc.) (Mauzy, 1997, p. 218), in general, '. . . it [the discourse] does not clearly distinguish Asians from Western conservatives' (Freeman, 1996, p. 357). Although Asian values explicitly eliminate them, Western values, i.e. the ideas of rights, freedom and liberty, also supplement Asian values; Asian values are not an Asian alternative to Western liberalism but an alternative in Asia to liberalism (Rodan, 1996, p. 337). This is because Asian values constitute neither religious nor cultural essentialism but a politicoideological project that calls for regional solidarity. 'It is rather an ideological programme for a joint community of believers. Its possible attraction in Asia lies in regional identity and a shared sense of belonging. . . Asian values thus have little to do with culture, but everything to do with ideology and political programmes...' (Öjendal and Antlöv, 1998, p. 538, my emphasis).

\section{Three specific Asian projects}

While the above discussion explored the articulation of Asian values, this section reviews three specific cases with regard to the debate on Asian values. Most of them occurred in the early 1990s and include the following. (i) A series of APEC summits during 1993-95 (Seattle, Bogor and Osaka), 
which increased the antagonism between the Asian and Anglo-Saxon members of APEC. (ii) An EAEC proposal; the Malaysian proposal of EAEC in 1990 constituted a direct challenge to APEC, because the EAEC advocated regional community-building among those who share Asian values. (iii) The Bangkok Declaration of 1993, according to which forty Asian states adopted the Asian stance on human rights issues, with a strong emphasis on Asian regional particularity.

\subsection{The series of APEC summits: Seattle, Bogor and Osaka}

The series of APEC summits represented both the articulation and disarticulation of open regionalism. The Seattle and Bogor summits played an articulating role, while the Osaka summit constrained and disarticulated open regionalism. At the Seattle summit of 1993, the member-states agreed to form an 'Asia-Pacific community' and the proposal at Seattle focused on more progressive trade liberalization and facilitation. The Bogor summit of 1994 identified the objective of trade liberalization; the member-states reached numerous agreements, although some of them were controversial. These agreements included the goal of complete liberalization, by the year 2010 for advanced economies, and by 2020 for developing members. Another agreement was that APEC liberalization would be extended to non-members in order to encourage open regionalism and discourage Asian economic regionalism (Funabashi, 1995; Das, 2001).

However, clashes within APEC gradually emerged with regard to liberalization policies (Wesley, 2001). The Bogor Declaration, a proposal for trade liberalization by 2010 and/or 2020, was identified as 'potentially the most far-reaching trade agreement in history' (Bergsten, 1994, p. 20). However, several Asian leaders were reluctant with regard to President Clinton's call for a 'Pacific Community' (Akaha, 1999) and saw the Seattle summit as a 'reassurance of America's continued commitment to the region' (Funabashi, 1995, p. 79). More importantly, the biggest challenge to the US initiative was posed by Malaysia, which boycotted the summit and advocated caution in the face of the rapid pace of liberalization. Rafidah Aziz, Malaysian Trade Minister, noted that 'Malaysia is worried and chary about accepting any recommendation that will radically change the original mandated form and profile of APEC beyond what it is supposed to be' (interviewed by Funabashi, 1995, p. 85). Following this initiative, China, Indonesia, the Philippines and Thailand aligned with Malaysia against rapid economic liberalization.

The Osaka Declaration of 1995 reflected the antagonistic realities within APEC; the Declaration stated that APEC neither forms free trade zones nor discriminates against non-member countries, and that it facilitates the liberalization of trade and investment by promoting economic and technical 
co-operation (Akaha, 1999). This Declaration was much more toned down than the Declarations that had emanated from the previous two summits. Japan began to align with the Asian rather than the Anglo-Saxon members of APEC (Gilpin, 1997; Rapkin, 2001; Webber, 2001). Japan also placed greater emphasis on its Asian identity and the construction of an integrated regional economy as an alternative strategy. This has been referred to as the 're-Asianisation of Japan' (Funabashi, 1995), a suggestion that Japan has 'rediscovered its Asianness' (Gilpin, 1997) or 'neo-Asianism' (Higgott and Stubbs, 1995). An internal MITI memo noted that the economic liberalization initiated by the United States seems to be 'forcing Minor League players to play in Major League games', and continues to argue against the negative effects of the US approach to APEC. ${ }^{7}$ Accordingly, the US approaches lack 'appreciation for the policy effects as well as economic impacts' and 'consideration for the different stages of economic development' of member countries (quoted by Funabashi, 1995, pp. 121, 131). One MITI official commented that, 'Liberalisation and cooperation should be pursued with equal weight and emphasis, as if they were two wheels of a car' (Funabashi, 1995, p. 122). One Japanese diplomat notes 'The US position on liberalisation is not based on a long-term perspective. They do not want a unilateral approach. At the same time, they do not want structure either.' Another diplomat argued that 'the US has neither the will nor the ability to liberalise further. They still have a 30 to 40 per cent tariff on textiles, 25 per cent on trucks, and double-digit percentages on glass. They have continued to protect these areas ...' (both cited by Funabashi, 1995, p. 97).

These antagonisms led to a clash of economic ideologies between open regionalism (or extreme liberalization) and the 'flying geese' strategy (or traditional developmentalism). The three successive summits witnessed a decline in the globalist tenor of open regionalism and the resurgence of the flying geese strategy and developmentalism. Table 4 summarizes the features of open regionalism, the flying geese model and developmentalism. While open regionalism endorses the global integration of markets and promotes the liberalization process, developmentalism constitutes an economic nationalism that focuses on national and protectionist economic strategies. The flying geese theory maintains a middle path. It is a region-based developmental strategy. There are leading (developed) and follower (developing) geese, and the latter develop their economic competitiveness through economic co-operation with the former. Indeed, the leading countries export useful materials and techniques to the follower countries, and the follower

7 At the Osaka summit, MITI's stance was somewhat ambivalent. Although some MITI officials intended to promote open regionalism and bridge the gap between globalism and regionalism, many other documents expressed concern at the rapid liberalization initiated by the United States. 
Table 4 Open regionalism, the flying geese model and developmentalism

\begin{tabular}{llll}
\hline & Open regionalism & Flying geese model & Developmentalism \\
\hline Perspective & Liberalism & Intermediate & Protectionism \\
Focus & Global & Regional & National \\
\hline
\end{tabular}

countries employ an import-substitution strategy by adopting appropriate labour-intensive industrialization, and learn from the leading countries. The wave of development then spills over from developed to developing countries in the region. In other words, it is a theory of economic co-operation rather than liberalization, and Japanese development and aid strategies in East Asia have relied on this theory for several decades. ${ }^{8}$ Although Japan articulated open regionalism in the first half of the 1990s, it gradually reverted to the flying geese strategy. The growing antagonism also highlights a dichotomy between the flying geese strategy and open regionalism. The political struggles at the series of summits led many Asian countries to the conclusion that APEC needed to lay greater emphasis on economic and technical co-operation rather than trade liberalization (Ravenhill, 2000, p. 323).

\subsection{An EAEC proposal}

In December 1990, Mahathir formulated a proposal for an East Asian Economic Grouping (EAEG), later renamed as the EAEC. This proposal focused on 'East Asian' identity rather than the 'Asia-Pacific' understanding of the region that was promoted by APEC. The proposal showed an inclination towards restricting membership to East Asian members (Nishiguchi, 1993; Onozawa, 1993; Bowles and MacLean, 1996; Funabashi, 1995; Higgott and Stubbs, 1995). ${ }^{9}$

Mahathir emphasized 'a strong voice for East Asian countries in trade negotiations with the rest of the world, particularly the EC and NAFTA' (quoted in Saravanamuttu, 1992, p. 7). He argued that EAEC has 'a population of more than a billion, with huge economic clout, people will have to listen ... this group of countries seems to have something in common both with regard to attitudes towards economic development and also culturally' (Mahathir, 1993, p. 11). Anwar, the Malaysian Finance Minister, also stated

8 Korhonen (1994a,b) provides a helpful discussion of the flying geese theory. In reality, the impact of the theory on Japan's policymaking is massive. Numerous official documents continuously refer to the theory and assert that East Asian economic success has demonstrated the validity of the so-called flying geese model (see, for example, Economic Planning Agency, 1994).

9 Members, according to the proposal, would include Brunei, Hong Kong, Indonesia, Japan, the Philippines, Malaysia, Singapore, South Korea, Taiwan and Thailand. China and other Indochinese countries were also identified as prospective members. 
that 'The East Asian Group should be able to sit with North America or Europe on an equal footing. This would not be possible if we relied on APEC because the US and Canada also belong to the North American Free Trade Area' (quoted from Camroux, 1993, pp. 33-34). Chandra, a Malaysian activist, argues that "As a concept, "Asia-Pacific" makes little sense. Unlike East Asia or South Asia or Southeast Asia, it has no shared history or common cultural traits. Asia-Pacific is not even an accepted geographical entity' (Chandra, 1993, p. 13).

Furthermore, the proposal for the EAEC was sometimes associated with the liberalization debate. The anti-liberalization group supports regional cooperation mechanisms such as the EAEC. José Concepcion, the Philippines Secretary of the Department of Trade and Industry, emphasized the necessity of managing 'Asia for Asians' (quoted by Funabashi, 1995, p. 122). Although Malaysia gave strong backing to the EAEC proposal at the 1992 ASEAN summit in Singapore, most of the ASEAN members were reluctant to accept the idea of an exclusively Asian regional body. The EAEC was instead accepted as a caucus within the APEC framework at the ASEAN foreign ministers' meeting in 1993 (Higgott and Stubbs, 1995, pp. 522-523). Furthermore, Japan's position towards EAEC was ambivalent; it neither sided with nor directly opposed the proposal (Low, 1991; Onozawa, 1993; Hook, 1996). ${ }^{10}$

While the proposal failed, the EAEC marked the beginning of an advocacy of regional identity, an articulation of Asian regionalism. '[A] less explicit claim on the EAEC's behalf may be the shared commitment among its members to those "Asian values" that, in the views of some, undergird Eastern Asia's economic prosperity. In this sense, the EAEC idea is geared to an Asian identity' (Acharya, 1997, p. 338). On the one hand, the EAEC constitutes a defensive Asian reaction to Western regionalisms such as the EU and NAFTA (Funabashi, 1993). On the other hand, Mahathir's proposal promotes the idea of Asian regional identity. Since the miserable results of Japan's attempt to create a Greater East Asian Co-Prosperity Sphere in the 1940s, Asians have been loathe to endorse an exclusively Asian regionalism (or the construction of an Asian community). However, Mahathir's proposal recognised the potential for Asian regionalism in the early 1990s, and an idea similar to the EAEC led to the creation of the Asian Monetary Fund

10 As one Japanese diplomat notes, the proposal of an EAEC 'came too early and caught Japan off guard'. A Malaysian MITI minister stated that 'it was strange that Japan must always comply with the United States' (quoted by Funabashi, 1995, pp. 205-206). Also, Japanese Prime Minister Miyazawa Kiichi visited Malaysia in January 1993, and emphasized the necessity of US involvement in the region and the obstacles to Japan's participation in the EAEC (Onozawa, 1993, p. 277). 
(AMF) and the ASEAN+3 (APT) in the late 1990s. 'Mahathir's proposal removed the taboo on Second World War types of depictions of Asia. The EAEC comprises roughly the same region that the Japanese Greater East Asian concept did, further incorporating Japan into the same group with other East Asian countries' (Korhonen, 1997, p. 359).

\subsection{The Bangkok Declaration}

At the conclusion of the United Nations Asia Regional Meeting on Human Rights in April 1993, the Bangkok Declaration was adopted by forty Asian countries (including the Middle East, and excluding Japan) (Mauzy, 1997, pp. 220-221). The Declaration maintained that rights are 'universal in nature', but they need to be arranged according to the context of national, regional, cultural and religious particularities. ${ }^{11}$ The Bangkok Declaration also maintained an anti-American or anti-Western practice by 'emphasising the role of culture and stage of development, placing economic and social rights ahead of individual rights ...' (Manning and Paula, 1994, p. 87).

Opposing Western critiques of Asian values, Asians have countered that there need to be different interpretations and implementations according to regional particularities, although rights are universal and natural. In short, the Bangkok Declaration was a regional response to the attempted universalization of Western norms of human rights. 'Asia's particularist approach to human rights issues, which seems to solidify Asian countries against the West, may well hamper Asia from building itself into a community with civic spirit beyond its national borders' (Funabashi, 1993, p. 84). A year later, the Chinese Premier Li Peng endorsed the declaration and argued that 'there is not just one model of human rights. . . While emphasising general human rights, we cannot neglect the characteristics of the country and region and the importance of historical, cultural, and religious backgrounds. We cannot neglect each countries' conditions and cannot demand a singular model of human rights' (quoted by Ong, 1999, p. 75).

Furthermore, Asian NGOs play an interesting role in the Asian values debate. Some Asian NGOs distance themselves from Western human rights NGOs (Mauzy, 1997), because Western NGOs have been perceived as 'agents of the one-sided conception of human rights that reinforces patterns of global dominance' (Falk, 1994). Malaysian academics and social activists note that although some notions of the Western style of human rights are acceptable, there are a number of elements which run counter to Asian values taken in their entirety (Mauzy, 1997, p. 222). For instance, Just World Trust, a Malaysian NGO, has strongly attacked the West in general and the

11 The Bangkok Declaration, adopted at the UN Asia Regional Meeting on Human Rights in Bangkok, 29 March-2 April 1993. 
United States in particular. Chandra Muzaffar, the founder of this NGO, argues that colonialism has been the most massive and structural violation of human rights in history, and that by pressing with regard to human rights issues, the West attempts to maintain its global domination of an unjust and unequal system (Muzaffar, 1993). In sum, suspicion of the West has been shared not only by Asian governments but also many Asian NGOs (Mauzy, 1997).

\section{Rediscovering Asianness}

Previous sections of this paper reviewed the articulation and disarticulation of open regionalism and Asian values, considering three specific cases of discursive practice. This section evaluates how these discursive practices have rediscovered Asianness. Growing tensions between Asia and the West have gradually constituted the discourse on Asianness. 'The growing interdependence of the Asia-Pacific has come when many Asians are rediscovering their "Asianness". This apparent contradiction has led many to suffer from identity crises of self and community' (Funabashi, 1995, p. 32). The first subsection offers a theoretical account of discursive relations between Asia and the West. Although Asia propagates its resentments, it still relies on U.S. regional commitment, what Derrida calls the 'logic of supplement'. The second subsection explores the articulatory and disarticulatory relationship between open regionalism and Asian values, considering three specific cases in practice.

\subsection{A Derridian effect: wakon yosai/zhong ti xi yung}

Although numerous discursive practices have constructed and deconstructed APEC, this does not imply an Asian isolationism. An emphasis on Asian values does not mean a complete departure and withdrawal from the West. The clearest analogy is Asia's programme of 'modernization without Westernization' in the nineteenth century (i.e. Japan's wakon yosai and China's zhong ti xi yung). ${ }^{12}$ This concept plays a crucial role in understanding Asian values and the discourse on Asianness, since today's Asian regionalism constitutes a new modernization that excludes Westernization.

In principle, while fostering their native cultures and eliminating Western ideas and values, Japan and China also reaped the benefits of Western

12 Wakon yosai means Japanese spirit, Western learning. Although it introduced elements of the modern Western state system (e.g. Western-style bureaucracy and administration, school education, legal and electoral structures and industrial and economic development), Japan did not incorporate Western schemes of ideas and values (e.g. Christian humanism and enlightenment philosophy) (Oga, 2003). Zhong ti xi yung means 'Chinese learning for the fundamental principles, Western learning for practical applications’ (Teng and Fairbank, 1965). 
knowledge and technology. This is what Derrida (1976) calls 'the logic of supplement'; despite the hierarchical dichotomy between the inside and outside, both are synthesized in the form of origin and supplement. An outside (supplement) supplements the lack of inside (origin); although it excludes the outside, the inside is also supplemented by the outside, since '. . identity is only possible to the extent that the "inside" is "supplemented" by the "outside", (Smith, 1994, p. 73). As Derrida puts it,

The question is of an originary supplement, if this absurd expression may be risked, totally unacceptable as it is within classical logic. Rather the supplement of origin: which supplements the failing origin and which is yet not derived: this supplement is, as one says of a separate part [une pièce], of the original make [origine] [or a document, establishing the origin].

(Derrida, 1976, p. 313).

In light of this, Asian values exclude the Westernization of the region, while Western notions such as democracy and human rights constitute the outside, and supplement the lack of Asian values inside. For instance, as Aihwa Ong notes, the 'overseas Chinese are viewed as possessing and deploying Western knowledge and skills without becoming inferior versions of Occidentals . . but they express their instrumental rationality in an inherently "Chinese" manner - a reverence for Confucian discipline and solidarity and the use of guanxi networks' (Ong, 1999, p. 52). Likewise, Singaporean official George Yeo asserts that 'no democracy can function without strong moral underpinnings supported by the entire community. Democracies which see only rights without obligations eventually destroy themselves' (Yeo, 1994).

This does not mean that Asian values are alternatives to democracy, but that they can be interpreted differently. A duality of exclusion and supplementarity appears in the discourse on Asianness in many ways; neither real opposition to nor synthesis with the West.

Despite the emphasis placed on a new sense of common identity as a facilitator of united East Asian action to balance Western economic dominance, the post-crisis initiatives taken by several East Asian governments have been directed as much at forging closer links with Western partners as at constructing an exclusive East Asian bloc. (Ravenhill, 2002, p. 191)

Accordingly, despite strong endorsement of an Asian regionalism, East Asia is still strongly linked to international politics, although East Asian countries attempt to revise and adjust their policies on their own terms. This does not mean that Asia abandons all mechanisms learnt from the West and withdraws from the international arena. Asia never closes the door to the external world, but it does revise and readjust Western models. 
The logic of supplementarity appeared in a number of statements by Mahbubani, Foreign Minister of Singapore. On the one hand, he attacks the West in general and the United States in particular in that they mistakenly believe 'that others will model themselves after Europe, that the natural progression of history will lead to all societies becoming liberal, democratic, and capitalist. This assumption creates an inability to accept that other cultures or social forms may have equal validity' (1995, p. 105). On the other hand, he also acknowledges the usefulness of Western knowledge and methods:

The region must also accept that the march of technology is irreversible.

The Internet, fax machines, and satellite TV have opened up every society in the Asia-Pacific. . . . The East Asian middle class, whose number will soon approach 500 million, is developing an understanding of American society's strengths and weaknesses. Its members can make informed choices about the kind of society that they want to create for themselves.

(Mahbubani, 1998, p. 155)

This is a dual logic of origin and supplement. While resisting the Westernization of the region, the external West, at the same moment, supplements the Asian inside. As Mahbubani (1998) says, 'The Asian renaissance is here to stay, with or without American involvement.' Likewise, Aihwa Ong states that:

At a broader regional level, East Asian and ASEAN countries often take a common moral stance - saying no to the West - to the epistemic violence wrought by neoliberal orthodoxy, but at the same time, they disguise their own investment in the rationalities of global capitalism. Globalisation in Asia, then, has induced both national and transnational forms of nationalism that not only reject Western hegemony but seek, in panreligious civilisational discourses, to promote the ascendancy of the East.

(Ong, 1999, p. 18, my emphasis)

This supplementarity of Asianness has survived even in the late 1990s. Although the US-Japan alliance has been strengthened, Japan has adopted anti-US and anti-IMF stances in the wake of the Asian financial crisis (Cox, 1999; Webber, 2001). The smooth development of ASEAN-led co-operative initiatives such as the ASEAN Free Trade Area and the ASEAN Regional Forum has also demonstrated supplementarity between Asianness and liberalization discourses (Nischalke, 2000, 2002): Asianness does not constitute a full rejection of liberalism and the US commitment. Finally, the financial crisis strengthened, not weakened, the discourses on Asian values. A number of institutional frameworks, most notably APT, constitute an exclusively 
Asian regionalism, rather than a revival of open regionalism (Milner, 2000; Webber, 2001; Ravenhill, 2002).

\subsection{Asian values as an institutional discourse}

As a whole, Asian values have played a number of important roles in dissolving the APEC frameworks. These discursive practices radically antagonized the West, which constituted the outside. The constitution of the Asian values discourse appears in critical response to the West: the failure to reach substantive agreement at a series of APEC summits was attributed to Asia's antagonism of the West. The political purpose of the EAEC proposal was to challenge Western regionalism (EU, NAFTA); instead it articulated the idea of an exclusively Asian regional community. The Bangkok Declaration criticized Western approaches to human rights issues. It was argued that '. . . to the degree that there is a sense of identity, it tends to be Asian, not Pacific: an assertive Confucian culture; an informal, non-confrontational style; and the self-confidence of the newly industrialising economies as successful postcolonial, non-white societies' (Manning and Paula, 1994, p. 81).

However, the resurgence of Asian values does not entail regional isolationism For instance, Korean President Kim Dae Jung asserts that 'genuine Asian values do not run counter to democracy, but coincide with it' (1998). A discourse on Asianness constitutes dual logic, exclusion and supplementarity. Figure 3 shows an overall picture ranging from open regionalism to Asian regionalism. Overall, an articulation of open regionalism appeared as a counter to exclusive regionalism, while it failed to construct a region-wide identity. The demand of liberalization is floating for member-states. In contrast, a number of discursive practices deconstruct the

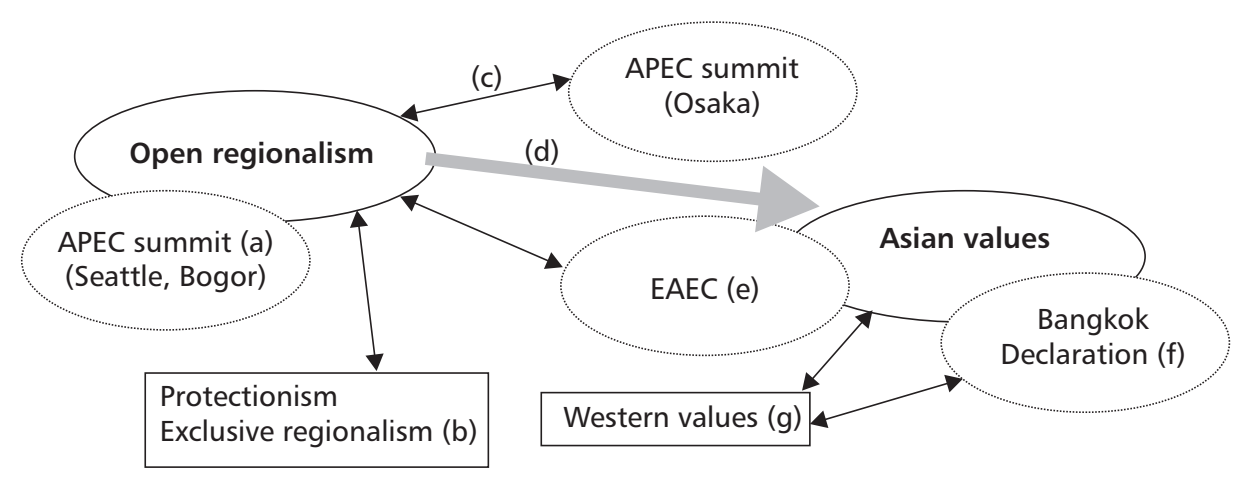

Figure 3 From open regionalism to Asian regionalism. (a) The articulation of open regionalism at the Seattle and Bogor summits. (b) Antagonism towards the idea of exclusive regionalism. (c) Disarticulation of open regionalism at the Osaka summit. (d) The hegemony of Asianness is articulated through numerous discursive practices. (e) The articulation of the EAEC. (f) The articulation of the Bangkok Declaration. (g) Asian values as a rejection of Western values. 
framework of the APEC under the emptiness of Asianness; Asianness does not possess fixed content but is articulated as a critical response to the West.

\section{Conclusion}

This paper has attempted to explore how changes in institutional discourses can explain the evolution of APEC by investigating two institutional discourses: open regionalism and Asian values. Opposing the realist perspective, we can see that power does not necessarily change institutional discourses, since there have been no changes in the distribution of power capability between the first and second half of the 1990s. Opposing the institutionalist perspective, interests do not always matter, since a shift from open regionalism to Asian regionalism cannot be seen as based on interests but rather on identity. There have been no rational reasons for Asian states to be regionally oriented, because most rely on the United States for economic support and security. Power and interests are rather shaped by discourses. Discourse theory may thus provide an alternative to existing perspectives: institutional discourses play a certain role in explaining the rise and decline of international regimes, as demonstrated in this paper.

\section{Acknowledgements}

This paper is one of the crucial parts of my $\mathrm{Ph}$.D. thesis, which was submitted to the Department of Government, University of Essex. An early version was presented at the Fourth Essex Conference of Political Theory on May 2003, and mostly written at the University of Tsukuba, where I undertook research during 2002-3. Numerous people encouraged me and gave me fruitful feedback. I am particularly grateful to Jason Glynos, Sumio Hatano, David Howarth, David Houghton, Michael Strange, Richard Stubbs and Barbara Weiss, as well as to anonymous IRAP reviewers.

\section{References}

Acharya, A. (1997) 'Ideas, identity, and institution-building: from the ASEAN way to the Asia-Pacific way', Pacific Review, 10(3).

Adler, E. (1992) 'The emergence of cooperation: national epistemic communities and the international evolution of the idea of nuclear arms control', International Organization, 46(1).

Adler, E. (1997) 'Imagined (security) communities: cognitive regions in international relations', Millennium: Journal of International Studies, 26.

Akaha, T. (1999) 'Asia-Pacific regionalism and Northeast Asia subregionalism', paper presented at the ISA Convention, Washington.

Bergsten, F. (1994) 'APEC and world trade: a force for worldwide liberalization', Foreign Affairs, 93(3). 
Bowles, P. and MacLean, B. (1996) 'Regional trading bloc: will East Asia be next?', Cambridge Journal of Economics, 20.

Buzan, B., Wæver, O. and Wilde, J. D. (1998) Security: A New Framework for Analysis. London: Lynne Rienner.

Camroux, D. (1993) Looking East and Defining Inward: Malaysia as a Self Conscious Middle Power During the Mahathir Era 1981-93. Brisbane: Centre for the Study of Australian-Asian Relations, Griffith University.

Chandra, M. (1993) 'APEC serves interests of US more than others', New Straits Times, 29, July.

Cox, R. (1999) 'Civil society at the turn of the millennium: prospects for an alternative world order', Review of International Studies, 25.

Das, D. K. (2001) 'Regionalism in a globalising world: an Asia-Pacific Perspective', working paper CSGR No. 80/01, University of Warwick.

Derrida, J. (1976) Of Grammatology, trans. G. Spivak. Baltimore, MD: Johns Hopkins University Press.

Dupont, A. (1996) 'Is there an “Asian way”?', Survival, 38(2).

Economic Planning Agency (1994) White Paper on the World Economy. Tokyo: Economic Planning Agency.

EPG (1994) Achieving the APEC vision: Free and Open Trade in the Asia-Pacific. Second Report of the Eminent Persons Group to APEC Ministers, August.

Falk, R. (1994) 'The dominance pattern in the West: deforming outlook, deformed practices', revised paper prepared for the International Conference on 'Rethinking Human Rights', Kuala Lumpur, 6-7 December.

Flyvbjerg, B. (2001) Making Social Science Matter. Cambridge: Cambridge University Press.

Freeman, M. (1996) 'Human rights, democracy and "Asian values", Pacific Review, $9(3)$.

Fukuyama, F. (1993) The End of History and the Last Man. Harmondsworth: Penguin.

Funabashi, Y. (1993) 'The Asianization of Asia', Foreign Affairs, 72(5).

Funabashi, Y. (1995) Asia Pacific Fusion: Japan's Role in APEC. Washington, DC: Institute for International Economics.

Gilpin, R. (1981) War and Change in World Politics. Cambridge: Cambridge University Press.

Gilpin, R. (1997) 'APEC in a new international order', in D.C. Hellman and K.B. Pyle (eds), From APEC to XANADU. New York: M.E. Sharpe.

Gilpin, R. (2000) The Challenge Of Global Capitalism. Princeton, NJ: Princeton University Press.

Goh Chok Tong (1994) 'Three lessons for Singapore', Straits Times, 27 August.

Gramsci, A. (1972) Prison Notebooks, ed. Q. Hoare and G.N. Smith. London: Lawrence and Wishart.

Griggs, S. and Howarth, D. (2000) 'New environmental movements and direct action protest: the campaign against Manchester Airport's second runway', in D. Howarth et al. (eds), Discourse Theory and Political Analysis. Manchester: Manchester University Press. 
Haas, P. (1992) 'Introduction: epistemic communities and international policy coordination', International Organization, 46(1).

Hall, R. (2003) 'The discursive demolition of the Asian development model', International Studies Quarterly, 47(1).

Hasenclever, A., Mayer, P. and Rittberger, V. (1997) Theories of International Regimes. Cambridge: Cambridge University Press.

Hitchcock, D. (1994) Asian Values and the United States: How Much Conflict? Washington, DC: Centre for Strategic and International Studies.

Higgott, R. (1997) 'Ideas and identity in the international political economy of regionalism: the Asia-Pacific and Europe compared', Kokusai Seiji [International Relations], 114.

Higgott, R. and Stubbs, R. (1995) 'Competing conceptions of economic regionalism: APEC versus EAEC in the Asia-Pacific', Review of International Political Economy, 2(3).

Hoffman, A. and Knowles, V. (1999) 'Germany and the reshaping of Europe: identifying interests - the role of discourse analysis’, ESRC-IGS Discussion Paper, 99/9.

Hook, G. (1996) 'Japan and the construction of the Asia-Pacific', in A. Gamble and A. Payne (eds), Regionalism and World Order. London: Macmillan.

Howarth, D. (2000) Discourse. Buckingham: Open University Press.

Huntington, S. (1993) 'Why international primacy matters', International Security, 17(4).

Huntington, S. (1996) The Clash of Civilizations and the Remaking of World Order. New York: Simon and Schuster.

Kahler, M. (1995) International Institutions and the Political Economy of Integration. Washington, DC: The Brookings Institution.

Keohane, R. (1984) After Hegemony. Princeton, NJ: Princeton University Press.

Keohane, R. (1988) 'International institutions: two approaches', International Studies Quarterly, 32.

Keohane, R. (1996) 'International relations, old and new', in R. Goodin and H. Klingemann (eds), A New Handbook of Political Science. Oxford: Oxford University Press.

Kindleberger, C.P. (1973) The World in Depression 1929-39. Berkeley: University of California Press.

Kim Dae Jung (1998) Remarks at a dinner hosted by Los Angeles Mayor Richard Riordan, 12 June (http://www.cwd.go.kr/cgi-bin/php/englib).

Korhonen, P. (1994a) 'The theory of the flying geese pattern of development and its implications', Journal of Peace Research, 31(1).

Korhonen, P. (1994b) Japan and the Pacific Free Trade Area. London: Routledge.

Korhonen, P. (1997) 'Monopolising Asia: the politics of a metaphor', Pacific Review, 10(3).

Krasner, S. (1976) 'State Power and the Structure of International Trade', World Politics, 28.

Krasner, S. (1983) International Regimes. Ithaca, NY: Cornell University Press.

Krasner, S. (1996) 'The accomplishments of international political economy', in 
S. Smith et al. (eds), International Theory: Positivism and Beyond. Cambridge: Cambridge University Press.

Kratochwil, F. (1988) 'Regimes, interpretation and the 'science' of politics: a reappraisal', Millennium: Journal of International Studies, 17(2).

Kratochwil, F. (1989) Rules, Norms, and Decisions: On the Conditions of Practical and Legal Reasoning in International Relations and Domestic Affairs. Cambridge: Cambridge University Press.

Kratochwil, F. and Ruggie, J. (1986) 'International organization: a state of the art on an art of the state' International Organization, 40(4).

Krauss, E. (2000) 'Japan, the US, and the emergence of multilateralism in Asia', Pacific Review, 13(3).

Laclau, E. (1990) New Reflections on the Revolution of Our Time. London: Verso.

Laclau, E. (1996) Emancipation. London: Verso.

Laclau, E. and Zac, L. (1994) 'Minding the gap: the subject of politics', in E. Laclau (ed.), The Making of Political Identities. London: Verso.

Low, L. (1991) 'The East Asian Economic Grouping', Pacific Review, 4(4).

Mahathir, M. (1993) 'A Prime Minister speaks', ASEAN-ISIS Monitor, 6 (April).

Mahathir, M. (1995) 'Let's have mutual cultural enrichment', New Straits Times, 16 March.

Mahathir, M. (2000) 'Agenda for New Asia', public speech, Asian Society, Hong Kong Centre, Hong Kong.

Mahbubani, K. (1995) 'The Pacific way’, Foreign Affairs, 74(1).

Mahbubani, K. (1998) 'Can Asians Think?', National Interest, 52.

Manning, R. and Paula, S. (1994) 'The myth of the Pacific community', Foreign Affairs, 73(6).

Mauzy, D. (1997) 'The human rights and "Asian values" debate in Southeast Asia: trying to clarify the key issues' Pacific Review, 10(2).

Mearsheimer, J. (1998) 'The false promise of international institutions', in M.E.Brown, O.R. Cote, S. M. Lynn-Jones and S.E. Miller (eds), Theories of War and Peace: An International Security Reader. Boston, MA: MIT Press.

Milner, A. (1999) 'What's happened to Asian walues?', working paper, Faculty of Asian Studies, Australian National University.

Milner, A. (2000) 'Asian consciousness and Asian values', working paper, Faculty of Asian Studies, Australian National University.

Muzaffar, C. (1993) Human Rights and the New World Order. Penang: Just World Trust.

Nischalke, T. (2000) 'Insights from ASEAN's foreign policy cooperation: the "ASEAN way", a real spirit or a phantom?', Contemporary Southeast Asia, 22(1).

Nischalke, T. (2002) 'Does ASEAN measure up? Post-Cold War diplomacy and the idea of regional community', Pacific Review, 15(1).

Nishiguchi, K. (1993) 'Toward an East Asian Free Trade Area', Japan Quarterly, January-March.

Oga, T. (2003) 'Constructing Meiji Japan: toward the politics of wakon-yosai', International Political Economy, 11.

Öjendal, J. and Antlöv, H. (1998) 'Asian values and its political consequences: is Cambodia the first domino?', Pacific Review, 11(4). 
Ong, A. (1999) Flexible Citizenship: The Cultural Logics of Transnationality. London: Duke University Press.

Onozawa, J. (1993) 'Japan and Malaysia: the EAEC test of commitment', Japan Quarterly, July-September.

Rapkin, D. (2001) 'The United States, Japan, and the power to block: the APEC and AMF cases', Pacific Review, 14(3).

Ravenhill, J. (2000) 'APEC adrift: implications for economic regionalism in Asia and the Pacific', Pacific Review, 13(2).

Ravenhill, J. (2002) 'A three bloc world? The new East Asian regionalism', International Relations of the Asia-Pacific, 2.

Robinson, R. (1996) 'The politics of Asian Values', Pacific Review, 9(3).

Rodan, G. (1996) 'The internationalisation of ideological conflict: Asia's new significance', Pacific Review, 9(3).

Ruggie, J. (1993) 'Territoriality and beyond: problematizing modernity in international relations', International Organization, 47(1).

Saravanamuttu, J. (1992) 'Malaysia's foreign policy in the Mahathir period 1981-92: an iconoclast come to rule', paper prepared for a conference on 'The Political Economy of Foreign Policy in Southeast Asia in the New World Order', Windsor, Ontario, 29 October-1 November.

Scollay, R. and Gilbert, J. (2001) New Regional Trading Arrangements in the Asia Pacific? Washington, DC: Institute for International Economics.

Shapiro, I. (2002) 'Problems, methods, and theories in the study of politics, or what's wrong with political science and what to do about it', Political Theory, 30(4).

Smith, A. (1994) New Right Discourse on Race and Sexuality: Britain 1968-1990. Cambridge: Cambridge University Press.

Teng, S-Y. and Fairbank, J. (1965) China's Response to the West: A Documentary Survey 1923-39. New York: Atheneum.

Terada, T. (2001) 'Directional leadership in institution-building: Japan's approaches to ASEAN in the establishment of PECC and APEC', Pacific Review, 14(2).

Torfing, J. (1999) New Theories Of Discourse. Oxford: Blackwell.

Turner, B. (1978) Marx and the End of Orientalism. London: Allen \& Unwin.

Wæver, O. (1995) 'Resisting the temptation of post-foreign policy analysis', in W. Carlsnaes and S. Smith (eds), European Foreign Policy: the EC and Changing Perspectives in Europe. London: Sage.

Wæver, O. (1996) 'The rise and fall of the inter-paradigm debate' in S. Smith et al. (eds), International Theory: Positivism and Beyond. Cambridge: Cambridge University Press.

Watanabe, A. and Kikuchi, T. (1997) 'Japan's perspective on APEC: community or association?', in D.C. Hellman and K.B. Pyle (eds), From APEC to XANADU. New York: M.E. Sharpe.

Webber, D. (2001) 'Two funerals and a wedding? The ups and downs of regionalism in East Asia and the Asia-Pacific after the Asian crisis', Pacific Review, 14(3).

Weldes, J. and Saco, D. (1996) 'Making state action possible: the United States and the discursive construction of "the Cuban problem" 1960-1994', Millennium: Journal of International Studies, 25. 
Wesley, M. (1997) 'The politics of exclusion: Australia, Turkey and definitions of regionalism', Pacific Review, 10(4).

Wesley, M. (2001) 'APEC's mid-life crisis? The rise and fall of early voluntary sectoral liberalisation', Pacific Affairs, 74(2).

Yamazawa, I. (2001) 'Asia-Pacific regionalism and Japan's strategy', Japan Review of International Affairs, 15(3).

Yeo, G. (1994) 'In Asia and elsewhere, small will be the better way to govern', International Herald Tribune, 22 June. 